\title{
Reducing the risk of hepatitis $B$ virus transfusion-transmitted infection
}

\author{
This article was published in the following Dove Press journal: \\ Journal of Blood Medicine \\ I5 July 201 I \\ Number of times this article has been viewed
}

\section{Christoph Niederhauser}

Blood Transfusion Service SRC, Bern, Switzerland
Correspondence: Christoph Niederhauser Blood Transfusion Service SRC Bern Switzerland, Murtenstrasse 133, 3008 Bern, Switzerland Tel +4I 3I 3842304 Fax +4I 3I 384320 I

Email christoph.niederhauser@bsd-be.ch
Abstract: Before 1970, approximately 6\% of multi-transfused recipients acquired a transfusion-transmitted Hepatitis B virus (HBV) infection. The safety improvements since then have been tremendous. From a level of a few infections per 1000 donations, the risk today, depending on the screening algorithm and additional measurements performed, has decreased to around 1:500,000 to $1: 1,000,000$, an improvement greater than 1000-fold compared to 50 years ago. This enormous gain in safety has been achieved through many factors, including development of increasingly more sensitive Hepatitis B antigen (HBsAg) assays; the adoption in some countries of hepatitis B core antibody (anti-HBc) screening; an improved donor selection procedure; HBV vaccination programs; and finally the introduction of HBV nucleic acid testing (NAT). Because there is a tendency in transfusion medicine to add one safety measure on top of another to approach the ultimate goal of zero risks, costs become increasingly a matter of debate. It is obvious that any new measure in addition to existing methods or measures will have very poor cost effectiveness. Therefore each country needs to perform its own calculation based on the country's own epidemiology, resources, political and public awareness of the risks, in order to choose the correct and most cost-efficient measures. Ideally, each country would make decisions regarding implementation of additional blood safety measures in the context of both the perceived benefit and the allocation of overall health care resources.

Keywords: hepatitis B virus, transfusion-transmitted infection, HBsAg, anti-HBc, NAT

\section{Introduction}

Since the milestone introduction of hepatitis B surface antigen (HBsAg) testing in 1969, the risk of transfusion-transmitted hepatitis B virus (TTHBV) has steadily decreased, thanks to the development of increasingly more sensitive HBsAg assays; the adoption in some countries of hepatitis B core antibody (anti-HBc) screening; improved donor selection, including nonremunerated intrinsically motivated blood donors; HBV vaccination programs; and finally the introduction of hepatitis B virus (HBV) nucleic acid testing (NAT) in minipools (MP) or later on as individual (ID) testing.

Several different approaches can be envisaged to reduce the risk of TTHBV. These vary according to the prevalence of $\mathrm{HBV}$ in a certain region; the extent to which a population is already vaccinated against HBV; the local economic situation; the availability of specific technical equipment; the availability of suitable donors; and the level of safety that is requested by the corresponding society. Based on these considerations, different algorithms can be foreseen, such as the sole serological approach with HBsAg; testing for HBsAg and anti-HBc; serology in combination with a less sensitive NAT (minipools); or on the other hand a highly sensitive ID NAT-only approach. 
Within these considerations it can be argued whether NAT should be dropped and antigen/antibody tests developed for more cost-effective screening strategy, or whether HBsAg testing could be dropped if an adequate sensitive NAT system was adopted. All these possible approaches have advantages and disadvantages and will be discussed in the present review. In the end, a balance between donor loss, economic reasons, required safety, and donor counseling has to be found for every country or region and an appropriate algorithm has to be defined.

\section{HBsAg testing}

A unique feature of the HBV life cycle is the production of large amounts of free HBsAg in the form of particles and filaments in vast excess to intact DNA-containing virions. This phenomenon makes HBsAg a very sensitive and useful marker of $\mathrm{HBV}$ infection, and HBsAg testing became the first-line screen for HBV. Over the past 40 years, the sensitivity of these tests has increased by $>2 \log _{10}$ as the technology advanced from crude immunological techniques to reverse passive hemagglutination (RPHA) and enzyme immunoassays (EIA), including enzyme-linked immunosorbent assays (ELISA), and the current assays now employing chemiluminescence (CLIA) detection.

There are more than 40 commercially available $\mathrm{HBsAg}$ assays currently in use around the world. Nevertheless, comparative studies have highlighted key differences in analytical detection sensitivities for HBsAg from wild type, mutant, and specimens of different genotypes among commonly used EIAs. ${ }^{1-6}$ The most sensitive assays detect HBsAg levels $\leq 0.1 \mathrm{ng} / \mathrm{mL}$, but significantly less sensitive methods with detection limits $>1 \mathrm{ng} / \mathrm{mL}$ still continue to be used worldwide. The CLIA sensitivity of $0.08 \mathrm{ng} / \mathrm{mL}$ corresponds to $102-267 \mathrm{HBV}$ DNA IU/mL as determined by NAT quantification of seroconversion panels, but can only be applied to the window period (WP) phase. . $^{78}$

Several other deficiencies with HBsAg assays have become apparent in recent years. During the 59 day window period (45-50 days for most sensitive assays) ${ }^{8-10}$ for $\mathrm{HBV}$ infection, HBsAg tests are not sensitive enough. Likewise in the early convalescence phase (core window) of HBV infection acute phase as well as in chronic HBV infections very low levels of HBsAg are often present, which are not detected by the routinely used HBsAg assays. ${ }^{11-25}$

Mutations associated with conformational and hydrophobic changes within and outside the immunogenic major hydrophilic region (MHR) of the S antigen, the main target for capture antibodies in commercial HBsAg assays, often lead to reduced synthesis or secretion of HBsAg. Such changes may account solely or in conjunction with other factors for the failure of immunoassays to detect HBsAg. ${ }^{5,26-31}$ There have been several reports on HBV escape mutants which were not detected by HBsAg screening assays. ${ }^{32,33}$ Bloodborne transmission of hepatitis B virus continues to occur despite implementation of highly sensitive screening tests for HBsAg, suggesting these assays are still not sensitive enough to prevent all infections..$^{20,24,34}$ Mutations may occur naturally from escaping active or passive immunity or antiviral therapy. The prevalence of such mutant strains may reach $\sim 30 \%$ in areas of high endemicity following vaccination programs. ${ }^{35,36}$ It has been suggested that the presence of anti-HBs in immune complexes with the whole virus or HBsAg may hamper the binding of HBsAg capture antibodies, thus leading to the failure of HBV screening assays. ${ }^{37,38}$

\section{Anti-HBc testing}

Unlike HBsAg, anti-HBc may be present during the chronic carrier state and at the end of an acute resolving infection where HBsAg may be undetectable. HBV-positive donors who are analyzed when they present during these stages of the disease can often be identified by either HBV-NAT or alternatively by testing for anti-HBc. Anti-HBc testing was introduced in several countries (for instance the US, Japan, and France) during the 1980s as a surrogate test for the so-called non-A, non-B Hepatitis. Testing for anti-HBc contributed at that time to the reduction in the number of post-transfusion hepatitis B cases in these countries. ${ }^{39,40}$ On the other hand, in HBV low-prevalence countries, a large proportion of the anti-HBc reactive blood donations may be false reactive, due to the lack of specificity of the available assays. ${ }^{41-43}$ The reason for this lies within the original development of anti-HBc tests. They were devised to test patients for suspected viral hepatitis rather than as a donorscreening assay and thus the sensitivity was increased over the specificity. ${ }^{44,45}$ Studies conducted in three low-prevalence countries (Germany, New Zealand, Switzerland) have shown that the anti-HBc tests currently used in blood bank settings have led to the loss of $2 \%, 2.5 \%$ and $6 \%-7 \%$, respectively, of otherwise eligible donors. ${ }^{46-48}$ In the US, it is estimated that around 500,000 donors were deferred due to isolated anti-HBc reactivity and it has been estimated that $65 \%$ of these deferrals were due to false positive results. ${ }^{42}$ Several studies conducted in Europe and in North America have shown that approximately $90 \%$ of blood donors positive for anti-HBc were also hepatitis B surface antibody (anti-HBs) positive, thus suggesting a recovered HBV infection. ${ }^{49}$ The 
majority of the remaining $10 \%$ of false-reactive anti-HBc samples could be explained by a poor assay specificity, whereas only a small fraction could be shown to be true anti-HBc positive..$^{50,51}$

Those cases which are solely anti-HBc reactive, the socalled anti-HBc alone or occult hepatitis B infection (OBI), deserve special consideration. There are several possible explanations for the anti-HBc alone profile: (i) a late acute resolving infection where $\mathrm{HBsAg}$ is no longer detectable but low-level HBV DNA may persist for a short time; (ii) a chronic carrier state, in the presence of anti-HBc, where HBsAg levels are below the detection limit of current assays; or (iii) $\mathrm{HBV}$ infection by a virus carrying mutations resulting in low level replication or altered HBsAg epitopes that are not detected by some HBsAg assays. ${ }^{31,52-54}$ These anti-HBc alone cases may originate either from recovered infections having lost detectable anti-HBs or from late chronic infections having lost detectable $\mathrm{HBsAg}$.

In some countries with a low level of HBV prevalence, deferring all anti-HBc reactive donors was considered affordable in terms of potential donations lost (eg, in the US, France, and Germany). In Germany a mandatory anti$\mathrm{HBc}$ test was introduced in October 2006 despite a long experience of minipool HBV NAT testing greater than three quarters of the German blood supply. ${ }^{55}$ It was estimated that anti-HBc testing would identify most OBI carriers, who are responsible for $50 \%-60 \%$ of all $\mathrm{HBs} A g$-negative but HBV positive donations. Only $67 \%$ of the OBI cases were identified by the current high sensitivity 96-member minipool NAT tests, whereas $87 \%$ of HBsAg negative preseroconverter cases were identified by minipool NAT. ${ }^{55}$ The loss of potential donors may be reduced if the anti-HBc positive donors are further tested with anti-HBs. Those donors who have an anti-HBV titer $\geq 100 \mathrm{IU} / \mathrm{mL}$ and are negative in single donation NAT (detection limit $\leq 12$ IU/) may be used for component preparation. In Japan, a country with moderate HBV endemicity, the algorithm for anti$\mathrm{HBc}$ assays has been modified in order to accept units with anti-HBs of $>2^{4}(\sim 200 \mathrm{MIU} / \mathrm{mL})$ even if the anti-HBc titer is $>2^{5}$ in conjunction with a negative HBV DNA test. ${ }^{56-58}$ Indeed to date no post-transfusion case has been documented since using this algorithm. ${ }^{56,59-62}$ High levels of anti-HBs is commonly accepted to be protective against transmission but there is at present no agreement on the threshold level though $100 \mathrm{IU} / \mathrm{L}$ is often cited. ${ }^{63}$ In many blood centers worldwide the introduction of these more sophisticated algorithms has not been introduced primarily for economic and organizational reasons.
The anti-HBc screening strategy is also not defendable in areas of the world where HBV is highly endemic, because an unacceptably large percentage of the potential blood donor population would be reactive and thus deferred from donation. ${ }^{25}$ Once donated, the number of units that would be rejected in these countries because of anti-HBc reactivity would be prohibitive to maintaining the blood supply. The two strategies left open in these areas are a serological testing algorithm with anti-HBc followed by anti-HBs or implementation of highly sensitive HBV DNA screening. The latter was adopted in the more affluent European Mediterranean countries, Poland, Singapore, Hong Kong, Taiwan, Thailand, and South Africa. ${ }^{64-69}$

In Switzerland, a low prevalence country, the decision against the introduction of anti-HBc testing was taken because the loss of approximately $2.5 \%$ of the otherwise healthy donor population was regarded as unacceptable. ${ }^{48}$ In this study, confirmation tests using two alternative anti-HBc assays reduced the number of reactive donations by approximately $60 \%$. These findings agree with two other studies, where it was shown that respectively $32 \%$ and $58 \%$ of blood donors, who were reactive in an initial anti-HBc assay, could not be confirmed with two additional assays. ${ }^{51,70}$ Thus it is difficult to evaluate precisely the exact rate of "false" positive reactions of the different available assays. Despite the potential loss of false HBV positive donors, anti-HBc testing still has a role in screening algorithms as it does reduce the residual risk of transfusion-transmitted HBV infection, by deferring potential HBV carriers from the donor population. The Paul Ehrlich Institute (PEI) reported that seven out of 18 cases of proven HBV transmission by blood components reported to this institute could have been prevented by anti-HBc testing. ${ }^{71}$ There is a strong need for more specific anti-HBc donor screening assays. Although in the last 5 years the diagnostic industry has improved the specificities of anti-HBc assays, there is still room for further improvement. Anti-HBc screening assays have the potential to exclude the majority of OBIs, leaving only rare cases of primary OBI or cases involving escape mutants associated with anti-HBs alone. On the other hand anti-HBc tests do not detect pre-seroconversion WP infections and they are not practicable in areas with anti-HBc prevalence $>5 \%$ where too many donor deferrals would negatively impact the blood supply.

\section{NAT testing}

The introduction of HBV NAT can overcome safety gaps left by $\mathrm{HBsAg}$ or anti-HBc testing, as it can potentially detect $\mathrm{HBV}$ in the very early acute phase, during the late chronic phase when very low HBsAg levels are often present, 
and can detect HBV escape mutants not recognized by HBsAg assays. In the late 1990s, NAT for HBV was introduced in several blood transfusion centers across Europe, as well as throughout Japan. It was hoped to identify HBV infected units during the early phase of acute infection, and in chronic carriers who often have undetectable levels of HBsAg. The initial NAT assays mostly analyzed pools of 16 to 96 donations. Since 1997 HBV NAT has been introduced as a routine screening assay in many countries with quite different HBV prevalence levels (1997 in Germany, 1999 in Japan, 2004 in Spain, 2005 in Poland, Ghana, French Antilles, and La Réunion, 2006 in Portugal and 2007 in Switzerland, Slovenia, Singapore, Hong Kong, Tawian, and Thailand). ${ }^{64-69,72,73}$

Blood donors suffering from an acute HBV-DNA positive infection and particularly those donating during the WP are likely to be highly infectious to transfusion recipients. ${ }^{62,74}$ Different studies have shown that HBV-NAT can significantly reduce the WP of HBsAg and this is even more effective when highly sensitive NAT testing assays are introduced. Since the introduction of HBV-NAT a number of potential WP donations have been identified. . $^{50,56,69,73,75-78}$

One study comparing seven currently used HBsAg tests with commercial HBV NAT in minipools of 16 or 24 donations (MP-NAT) or ID NAT showed the WP could be significantly reduced. In pools the WP was reduced by 9-11 days, resulting in a WP of 40-50 days. This reduction increased to 25-36 days when ID NAT was used leaving an effective WP of only 15-34 days. ${ }^{8,79}$ This study also showed that during the early ramp-up phase of infection, HBsAg tests detected only $31 \%-63 \%$ of a 100 -member HBV seroconversion panel compared with 55\%-71\% and 82\%-99\% detected by MP and ID NAT, respectively. ${ }^{79}$

There has been a recent debate over whether HBV NAT could eventually replace HBsAg tests. While both are direct viral detection assays, HBsAg has a shorter, more variable expression period than HBV DNA. A combination of HBV NAT and anti-HBc, especially if a highly sensitive NAT is implemented, should be preferable to HBsAg and anti-HBc screening. On the other hand, large-scale studies still need to be conducted to ensure that no incremental risk occurs if HBsAg screening is replaced by HBV NAT as a first-line screening assay. It is known that approximately $6 \%$ of HBsAg positive donations are expected to be nonreactive by MP NAT and $3 \%$ by ID NAT. ${ }^{50,80,81}$ HBsAg confirmed positive but HBV DNA negative donations are found in $2 \%-16 \%$ of all donations. ${ }^{69,80,82-84}$

A long-term persistent and intermittent viremia is not infrequent in isolated anti-HBc positive individuals following serological recovery from acute hepatitis B. ${ }^{17,19,30,50,85-88}$ Intermittent low level viremia may persist over very long periods of time, as shown in a case study of a blood donor who was intermittently polymerase chain reaction (PCR) positive for HBV DNA ( 8 to $260 \mathrm{IU} / \mathrm{mL}$ or 32-1040 copies) over 7 years. ${ }^{60}$ This suggests that clinical and serological resolution does not necessarily correspond to eradication of hepatitis B virus from infected hosts. Indeed the persistence of HBV DNA in serum during the convalescent phase after acute HBV has attracted attention as this HBV DNA is potentially infectious and thus may play a role in HBV transmission. ${ }^{86}$

As mentioned, previously anti-HBc positive, HBsAg negative blood samples often have persistent very low $\mathrm{HBV}$ DNA levels ranging from a few to 30 copies/mL..$^{51,73,79,81}$ Previous studies have shown that HBV DNA may be still be detected in up to $5 \%$ of the HBsAg negative, anti-HBc reactive blood donations. ${ }^{89,90}$ In countries such as China, Japan, Saudi Arabia, Ghana, Egypt, and Germany, HBV DNA was detectable in $0.3 \%$ to $15 \%$ of anti-HBc-only units. ${ }^{25,91}$ In another study conducted in the US the probability for the presence of HBV DNA in anti-HBc positive units lay between $1: 37,000$ and 1:54,000.92

OBIs are mainly found in older donors. Nearly $100 \%$ of these donors are anti-HBc reactive, and approximately $50 \%$ also carry anti-HBs suggesting that OBIs occur largely in individuals who have recovered from the infection but are unable to develop a totally effective immune control. ${ }^{93,94}$ The OBIs are usually characterized by very low plasma HBV DNA load $(<200 \mathrm{IU} / \mathrm{mL})$. As a consequence of this, the occurrence of viremia near the detection limit of the assay in these OBI donors and the potential for fluctuating HBV viremia in these individuals suggests that such donors, with ongoing HBV infection, would only be detected using highly sensitive NAT assays. . $^{89,64,73,79,95-97}$

Blood which is free of HBsAg but has high anti-HBc titers in the absence of anti-HBs, has the potential to transmit HBV. ${ }^{98,99}$ Studies published on post-transfusion hepatitis have shown that donations reactive for anti-HBc alone or for anti-HBc plus anti-HBs have transmitted HBV infection to transfusion recipients. ${ }^{11,15,98,100}$ In one reported case an OBI carrier transmitted HBV to two immunocompetent transfusion recipients despite the presence of anti-HBs. ${ }^{101}$ Apart from shortening the WP, NAT screening has uncovered a relatively large number of HBsAg-negative occult HBV donors. ${ }^{25,69,73,102}$

\section{Comparison of MP-NAT to ID NAT}

Early studies comparing HBsAg assays and HBV NAT in minipools showed that MP NAT was more sensitive than 
HBsAg assays,$^{78}$ whereas others showed that more recently developed sensitive HBsAg assays had a comparable sensitivity to MP-NAT. ${ }^{8}$ Since HBV has a particularly slow doubling time (2.6 days) it has been suggested that this may contribute to the greater difference between the sensitive and highly sensitive NAT assays. ${ }^{79}$ Model-derived estimates conducted in Europe, Japan, and the US, have generally been predictive of the yields of DNA positive, HBsAg negative WP blood units. These studies have indicated that the added benefit of NAT performed in pooled samples is relatively small in areas of low endemicity.

Several reports have estimated the risk of HBV transmission through $\mathrm{HBsAg}$ negative and anti-HBc positive donations to be approximately 1 in 50,000 donations. ${ }^{51,70,103}$ From 3.6 million German blood donations screened by HBV NAT in minipools of 96, only four donations were HBV DNA positive in minipools and these turned out to be also anti-HBc reactive..$^{50}$ If HBV NAT screening in minipools of 96 was routinely introduced, probably only one infectious donation in 900,000 donations would be detected and potential transfusion-transmitted infections avoided. However due to the low viral loads encountered in chronically infected donors, it seems unlikely that NAT in large minipools is sensitive enough to detect the majority of potentially infectious donations from anti-HBc positive donors. ${ }^{51}$ Chronically HBV infected donors are more effectively identified when highly sensitive ID NAT is used. ${ }^{50}$

In Japan, HBV DNA screening was introduced in 1999 using a MP-NAT system comprising 50 donations. Since its introduction, more than 500 seronegative but HBV DNA positive donations were detected. It was still believed, however, that units of blood in an early late phase of HBV infection with low viral loads were escaping detection by MP-NAT. ${ }^{62,104}$ The Japanese thus reduced their pool size from 50 to 20 . They could demonstrate that several pools which were NAT negative in 50 donation format were positive in the 20 donation format. ${ }^{105,106}$ Despite this improvement using a 20 MP NAT system, the risk of TTHBV could not been completely eliminated. It was believed the format was not sensitive enough to pick up extremely low levels of HBV, especially those observed in the chronic phase of HBV infections. ${ }^{57,62,104,107}$

\section{NAT yields}

HBV NAT yields for both WP and late-stage infection have been determined for several countries in the last decade (eg, the US, Germany, Austria, Switzerland, South Africa). ${ }^{46,47,69,73,81,108}$ Countries with low HBV endemicity such as Germany, Switzerland, New Zealand, the US, and Canada have reported
NAT yields ranging from $1: 4,000$ to $1: 730,000,{ }^{46,47,73,81,108-115}$ whereas for countries with moderate endemicity such as Poland and some Mediterranean countries, 1:4,000 to 1:51,987 has been reported, ${ }^{64,65,96,116-118}$ and countries with high endemicity such as Ghana, Hong Kong, India, South Africa the figure ranges from 1:186 to $1: 5,200 .{ }^{66-69,82,119-123}$

When comparing NAT yields it is essential to differentiate between calculations based on different screening strategies, such as those using NAT testing and HBsAg testing as opposed to NAT testing in combination with HBsAg and anti-HBc testing. If NAT was added to HBsAg and anti-HBc testing then the NAT yields are clearly less than those derived when NAT is added to HBsAg testing alone. In general, those areas highly endemic for HBV showed greater NAT yields than those with a lower endemicity. Individual sample NAT would offer more significant early WP closure and could prevent a moderate number of residual HBV transmissions not detected by HBsAg assays. ${ }^{124}$

\section{HBV NAT technologies}

Because automation has lagged behind NAT reagent development, testing MP of 16-96 samples was initially implemented as a temporary solution to allow processing of a large number of donor samples. Automated solutions have since been developed which promise to provide an efficient and cost-effective ID NAT testing strategy. In particular, the availability of commercial CE marked and FDA approved NAT systems, in multiplex format, detecting HIV, HCV, and HBV on automated testing platforms has opened up NAT screening for many transfusion centers worldwide. The two widely used assays are based on either a polymerase chain reaction (PCR) (s201 test system from Roche Diagnostics, Basel, Switzerland) or on transcription mediated assays (TMA) (Tigris from Novartis Diagnostics, Basel, Switzerland) and have specificities between $99.8 \%$ to $100 \%$ and very high sensitivities $<10 \mathrm{IU} \mathrm{mL} .{ }^{8,66}$ Thus, mass routine screening, which is efficient and cost-effective, is now feasible. Despite their availability many countries have either not yet introduced NAT screening or decided which pool size to use. It has been suggested that ID-NAT or NAT in small pools (Seight donations) will be required to impact HBV blood safety significantly. ${ }^{125}$ In 2009, the Swiss Blood transfusion Service Swiss Red Cross declared HBV NAT mandatory with a sensitivity of $25 \mathrm{IU} / \mathrm{mL}$ per donation. ${ }^{73}$

The ability of HBV NAT to reduce the WP depends not only on the sensitivity of the assay but also on a number of different aspects related to how the assay is set up, including the input volume used in the assay $(100-1000 \mu \mathrm{L})$; the dilution factor 
introduced by the pooling process; the use of sample concentration methods; the efficiency of nucleic acid extraction; and the analytical sensitivities of the amplification, and detection methods. ${ }^{8,56,59,126}$

\section{Cost effectiveness}

The original calculations on the cost-effectiveness of HBV IDNAT compared to MP-NAT were rather poor, particularly the costs per quality adjusted life year (QUALY). ${ }^{79,127}$ However since the development of the high throughput NAT systems the price differences between small MP-NAT and ID-NAT are negligible. There is still however a significant difference when 96 sample pool assays are used. Several medium-prevalence countries, such as Poland, prefer to use small MP-NAT of less than ten donations or even ID-NAT in order to circumvent anti-HBc testing, which is expected to lead to an unacceptable loss of blood donors. ${ }^{64}$ Likewise in Switzerland, a low prevalence country, ID-NAT or MP-NAT using six donations was introduced as an alternative to anti-HBc testing. ${ }^{73}$ The additional cost of small MP-NAT or ID-NAT must be compared to the cost entailed by anti-HBc testing and to the loss of otherwise eligible blood donors and to the marketing costs required to replace these deferred donors.

\section{Residual risks}

The calculation of residual risk of HBV transmission is dependent on a variety of factors. The pre-seroconversion WP is important, but so is the theoretical possibility of infection with immunovariant viruses, as well as the presence of donors with an occult carriage of HBV. Reduction of HBV residual risk is achieved by the development of more sensitive HBsAg assays; by introducing anti-HBc screening in certain communities; by the implementation of the HBV NAT technologies; HBV vaccination programs; and an array of other measurements.

The impact of more sensitive screening assays on the safety of the blood supply is estimated by the extent to which the new assay closes the infectious window period. This aspect is tested by analyzing HBV seroconversion panels and then projecting the effect of closure on the calculated residual risk of virus transmission. Using such panels the theoretical calculated residual risks for HBV from low endemic countries varies between 0.69 and 8.69 per million donations. ${ }^{81,111,128-135}$ In areas of moderate and high endemicity the calculated residual risks ranges from 7.5-15.8 and 30.6-200, respectively. ${ }^{129,136-138}$ All the measures introduced to reduce the residual risks of transfusion transmission of HBV have been helpful. ${ }^{139-141}$
The risk for HBV is quite difficult to estimate because of limited data for two of the key WP/incidence rate model variables. ${ }^{142}$ First of all the estimated 59-day infectious WP (range: 37-87 days) between HBV acquisition and seroconversion is unfortunately based on only a few transfusion cases, analyzed with older, less sensitive HBsAg assays. ${ }^{142}$ Secondly, HBV incidence is difficult to estimate, because $\mathrm{HBsAg}$ presence and persistence are quite variable. ${ }^{8,142}$ Risk models estimate HBV incidence extrapolated from the frequency of HBsAg presence in repeat donors. This is dependent on the length of presence of HBsAg postinfection and the inter-donation interval. While this marker generally correctly identifies incident cases in donors who were previously negative, it may underestimate the number of new infections, as in the inter-donation period recently infected donors may have already lost HBsAg. ${ }^{143}$ Finally, risk estimates based on seroconversion to anti-HBc will overestimate the true rate of new infections, because of the unacceptably high false-anti-HBc reactivity rate often observed in blood donors (up to $75 \%$ with older assays and up to $23 \%$ with currently used assays). ${ }^{138,144}$ Therefore an adjustment factor has been used by some authors to correct for this anomaly. ${ }^{142}$ An additional point which needs to be taken into consideration when estimating HBV risk is the large percentage of asymptomatic infections which lead to under-reporting, both in the general population and probably also in blood product recipients. Two investigations conducted in the US studied the impact of HBV NAT on residual risk. Kleinman and co-workers estimated that by implementing HBV NAT in pools of 24, one could potentially identify 39 infectious units from the WP and thus prevent 56 cases of TTHBV annually in the US.$^{81}$ Biswas and co-workers estimated that each day the WP was reduced translates into 1.4 additional HBV infections detected per 10 million screened donations. The 18 day reduction achieved by ID-NAT compared with HBsAg CLIA tests should identify an additional 2-3 HBV cases per million donors screened. ${ }^{8}$ Despite all these limitations, the published residual risk estimates seem to have some validity, as they tend to parallel the HBV endemicity in the population.

\section{Infectivity}

It has been suggested that anti-HBc and HBsAg testing could be eventually replaced by a highly sensitive HBV NAT. Compared to serological testing, HBV NAT has the additional ability to significantly reduce the WP and to detect occult HBV carriage. But before this can be done several questions still need to be addressed. What should be done with HBsAg or anti-HBc positive but HBV DNA negative donations: are they infectious? Blood that is collected during the early WP of HBV 
infection is highly infectious, but this risk declines as anti-HBs develops. ${ }^{74,145,146}$ In addition the blood transfusion community needs to know whether blood components from OBI donations are infectious. Clinical observations suggest fewer transmissions occur with OBI cases as compared to WP cases. These limited transmission rates may be related to the low viral loads generally observed in OBIs, the presence of defective variants associated with occult carriage, or the presence of anti-HBs. However, more recent data suggest that the neutralizing capacity of low antiHBs may be inefficient when encountered by exposure to high viral loads. Anti-HBc blood units without detectable anti-HBs appear moderately infectious except in immunocompromised recipients. An immunodeficient elderly patient or patients receiving immunosuppressive treatments may be exceptionally susceptible to infection with lower infectious doses even in the presence of anti-HBs. It has been shown that transfusion recipients are at an increased risk of a fatal $\mathrm{HBV}$ infection due to their age and comorbid conditions. ${ }^{34,147}$

Whether residual risk estimates translate into a true rate of infection is still largely unknown since estimates are generally based on the simplification that all HBV DNA-containing donations are infectious. In humans, transmission of HBV has been reported from donors in the pre-seroconversion window period and those donors with an occult HBV infection in which the HBV DNA load was below $20 \mathrm{IU} / \mathrm{mL}$. ${ }^{62,94,95,148}$ On the other hand transfusions from WP donors and those with an OBI were not infectious even though some had viral loads between 20 and $500 \mathrm{IU} / \mathrm{mL} .^{24,59,62,73,94,148}$ This lack of clear relationship between infectivity and viral load may be related to different causes, such as immune factors in the recipient; HBV infection phase of the blood donor; the volume of plasma transfused to the recipient; and the presence of HBV neutralizing antibodies. ${ }^{62,149}$

The situation in HBV vaccinated donors is rather less clear. In one study, blood donations that were positive for HBV DNA with detectable levels of anti-HBs were infectious in none of the 22 recipients, as compared with a rate of infection of $27 \%$ among 37 recipients of blood that was devoid of anti-HBs. ${ }^{62}$ Similarly the absence of infectivity in the presence of anti-HBs has been observed in other studies. ${ }^{60,99,150}$ Conversely, blood containing HBV DNA with low-level anti-HBs $(<75 \mathrm{IU} / \mathrm{L})$ may carry a risk of transmission leading to acute hepatitis. ${ }^{101}$

\section{Further measures to prevent TTHBV}

Viral pathogen-reduction processes and vaccination programs have the potential to reduce TTHBV.
Unfortunately, while viral reduction processes may be applied to platelet concentrates and plasma, the technology has not yet been satisfactorily applied to red blood cell components. Recently, viral reduction of platelets has been licensed in several countries. Published data show reduction rates sufficient for naturally occurring viral titers including HBV resulting in probably zero residual risk. However, in rare cases HBV can reach concentrations in the blood by which reduction procedures cannot be challenged. In addition, pathogen reduction procedures are complex, need sophisticated equipment and today are not capable of processing large amounts of blood products per day on a routine basis. Therefore viral reduction of red cell concentrates is not yet feasible, thus making additional tests inevitable. The cost for pathogen reduction procedure lies at present around $€ 170$ (Switzerland) for a single platelet unit, a cost efficiency that lies far above that of current laboratory testing including serology and NAT of any kind, even if testing were to be completely discontinued.

Immunization campaigns, if rigorously performed, are highly efficient in reducing the risk of TTHBV. However it would not be possible to perform such campaigns in all countries and it needs a continuance in the long run to ensure most of the blood donors have been vaccinated against HBV and thus to decrease the prevalence of HBV. The number of reports of acute HBV infections have declined in the past years, most likely due to better data quality and increasing protection against $\mathrm{HBV}$ provided by vaccination programs conducted in the general population. ${ }^{10} \mathrm{~A}$ decrease in $\mathrm{HBV}$ infection incidence was observed following $\mathrm{HBV}$ vaccine implementation in many countries with moderate or high HBV endemicity. ${ }^{151-153}$ However it may take many years or even decades to decrease the prevalence of $\mathrm{HBV}$ among blood donors, as the vaccine is at present usually only given to adolescents, newborns, and people at risk of exposure to HBV in their profession. Vaccination on the other hand may favor the development of escape mutants. AntiHBs in vaccinated people become undetectable over time and they are susceptible to HBV infection. In addition, up to 5\% of vaccinated individuals do not respond. ${ }^{15,154}$ These may pass undetected by HBsAg or HBV DNA testing. A study performed in the US screened 3,694,585 donations for HBsAg, anti-HBc, and HBV NAT. NAT testing was performed in individual donations for 576,940 donations $(10.4 \mathrm{IU} / \mathrm{mL})$ and 3,117,918 in MP of 16 donations. In total 426 donors were confirmed HBV positive. Nine NAT-only cases were found, including six samples from donors who had previously been vaccinated against HBV. These six donors had a brief transient course of infection with no evidence of disease and very low or absent expression of HBsA. ${ }^{115}$ The viral loads of the six HBV NAT 
cases varied from 11 to $86 \mathrm{IU} / \mathrm{mL}$. With highly sensitive NAT systems it should be feasible to detect most of these vaccinated but HBV DNA positive donors. HBV A2 is the parent strain for vaccination. All five vaccinated donors harbored all non-A2 HBV strains. It appears the vaccination is less effective against non-A2 HBV strains. In all vaccinated cases, during re-infection the ALAT levels were not elevated.

In another study, blood donations that were positive for HBV DNA with detectable loads of anti-HBs were not infectious in any of 22 recipients, as compared with the rate of infection of $27 \%$ among 37 recipients of blood that was devoid of anti-HBs. ${ }^{62}$ Similarly the absence of infectivity in the presence of anti-HBs has been observed in other studies. ${ }^{60,61,99,150,155}$ Conversely, blood containing HBV DNA with low-level anti-HBs $(\leq 75 \mathrm{IU} / \mathrm{mL})$ may carry a risk of transmission leading to acute hepatitis B. ${ }^{101}$ All in all, the significance of the potential for TTHBV from vaccinated or naturally infected anti-HBs positive donors is not yet clear.

\section{Summary}

Before 1970, approximately $6 \%$ of multi-transfused recipients acquired TTHBV. This risk has declined over the past 40 years, yet HBV transmission is still the most frequent transfusion-transmitted viral infection. ${ }^{156}$ Subsequent to the implementation of HBsAg screening and the elimination of most paid units, but prior to anti-HBc screening, it was shown that $0.3 \%$ to $1.7 \%$ of transfusion recipients developed HBV. ${ }^{157}$ The safety improvements made over the last 40 years have been tremendous. From the several infections per 1000 donations in the past, today the risk lies between 1:500,000 and 1:1,000,000 depending on the screening algorithm and additional measurements performed, which is an improvement in excess of 1000-fold compared to 40 years ago.

There is a tendency in transfusion medicine to add one safety measure on top of another to approach the ultimate goal of zero risk. However the incurring costs become increasingly a matter of debate and it is now obvious that any new measure added to the existing methods will have very poor cost effectiveness. Therefore each country needs to perform its own calculation based on local epidemiology, resources, and political and public awareness of the risks, in order to take the right and most cost-efficient measures. Ideally, each country would make decisions regarding implementation of additional blood safety measures in the context of both the perceived benefit and the allocation of overall health care resources. While the cost of NAT will vary depending on the infrastructure in place and the volume of units to be tested, there are three important factors that could impact a country's decision on whether or not to implement HBV NAT: firstly the prevalence of HBV in the country, which directly impacts the risk of TTHBV; secondly, the current use or appropriateness of the anti-HBc screening assays, along with an estimation of the fraction of HBV NAT-yield that would come from WP or late infections; and thirdly the decision to undertake pooled or individual NAT testing. Countries with a high prevalence have the highest risk of TTHBV and probably gain the most from HBV NAT. For low-prevalence countries that have already adopted HIV and HCV NAT for blood screening, the addition of HBV NAT, especially with the current commercially available multiplex NAT systems, requires no additional effort or cost.

Different approaches could be feasible. For instance, serology testing with HBsAg and anti-HBc could be envisaged; or serology in combination with NAT in MP (less sensitive NAT); or highly sensitive NAT only. Should NAT be suspended and antigen/antibody tests further developed for more cost-effective screening? Or would it be possible to replace serology if a highly sensitive HBV NAT system was in place? A combination of HBV NAT and anti-HBc, especially if a highly sensitive NAT is implemented, would be preferable to HBsAg and anti-HBc screening. Nevertheless, large-scale infectivity studies still need to be done to ensure no incremental risk occurs, if HBsAg or anti-HBc screening were to be discarded. Vaccination programs started must be continued and when possible extended. In addition to the safety of blood products these vaccination programs also bring benefit to the general population.

\section{Acknowledgment}

Thanks to Dr Peter Gowland for critical reading and drafting the manuscript.

\section{Disclosure}

The author reports no conflicts of interest in this work.

\section{References}

1. Zaaijer HL, Vrielink, Koot M. Early detection of hepatitis B surface antigen and detection of HbsAg mutants: a comparison of five assays. Vox Sang. 2001;81(4):219-221.

2. Weber B, Dengler T, Berger A, Doerr HW, Rabenau H. Evaluation of two new automated assays for hepatitis B virus surface antigen ( $\mathrm{HBsAg}$ ) detection. IMMULITE HBsAg and IMMULITE $2000 \mathrm{HBsAg}$. J Clin Microbiol. 2003;41(1):135-143.

3. Mizuochi T, Okada K, Umemori K, Mizusawa S, Sato S, Yamaguchi K. Reactivity of genotypically distinct hepatitis B virus surface antigen in ten commercial diagnostics kits available in Japan. Jpn J Infect Dis. 2005;58(2):83-87.

4. World Health Organization. Blood products and related biologicals. Available at: http://www.who.int/bloodproducts/en/. Accessed 2011 Jun 29. 
5. Moerman B, Moons V, Sommer H, Schmitt Y, Stetter M. Evaluation of sensitivity for wild type and mutant forms of hepatitis B surface antigen by four commercial HBsAg assays. Clin Lab. 2004;50(3-4): 159-162.

6. Olinger CM, Weber B, Otegbayo JA, Ammerlaan W, van der Taelem-Brulé N, Muller CP. Hepatitis B virus genotype E surface antigen detection with different immunoassays and diagnostic impact of mutations in the preS/S gene. Med Microbiol Immunol. 2007;196(4): 247-252.

7. Stramer SL. Pooled HBV DNA testing by nucleic acid amplification: implementation or not? Transfusion. 2005;45(8):1242-1246.

8. Biswas R, Tabor E, Hsia CC, et al. Comparative sensitivity of HBV NATs and HBsAg assays for detection of acute HBV infection. Transfusion. 2003;43(6):788-798.

9. Seed CR, Cheng A, Ismay SL, et al; Virology Subcommittee of the National Donor and Product Safety Committee, Australian Red Cross Blood Service. Assessing the accuracy of three viral risk models in predicting the outcome of implementing HIV and HCV NAT donor screening in Australia and the implication for future HBV NAT. Transfusion. 2002;42(10):1365-1372.

10. Offergeld R, Hamouda O, Burger R. Epidemiological data - an important part of the hemovigilance system. Transfusion Med Hemother. 2010;37(3):125-130.

11. Thiers V, Nakajima E, Kremsdorf D, et al. Transmission of hepatitis B from hepatits-B-seronegative subjects. Lancet. 1988;2(8623):1273-1276.

12. Kaneko S, Miller RH, Feinstone SM, et al. Detection of serum hepatitis B virus DNA in patients with chronic hepatitis using the polymerase chain reaction assay. Proc Natl Acad Sci US A. 1989;86(1):312-316.

13. Marcellin P, Martinot-Peignoux M, Loriot MA, et al. Persistence of hepatitis B Virus DNA demonstrated by polymerase chain reaction in serum and liver after loss of HBsAg induced by antiviral therapy. Ann Intern Med. 1990;112(3):227-228.

14. Blum HE, Liang TJ, Galun E, Wands JR. Persistence of hepatitis B viral DNA after serological recovery form hepatitis B virus infection. Hepatology. 1991;14(1):56-63.

15. Loriot MA, Marcellin P, Bismuth E, et al. Demonstration of hepatitis B virus DNA by polymerase chain reaction in the serum and the liver after spontaneous or therapeutically induced $\mathrm{HBeAG}$ to anti-HBe or HBsAg to anti-HBs seroconversion in patients with chronic hepatitis B. Hepatology. 1992;15(1):32-36.

16. Fong TL, Di Bisceglie AM, Gerber MA, Waggoner JG, Hoofnagle JH. Persistence of hepatitis B virus DNA in the liver after loss of HBsAg in chronic hepatitis B. Hepatology. 1993;18(6):1313-1318.

17. Michalak TI, Pasquinelli C, Guilhot S, Chisari FV. Hepatitis B virus persistence after recovery from acute viral hepatitis. J Clin Invest 1994;94(2):907. Erratum for J Clin Invest. 1994;93:230-239.

18. Zhang Y, Hansson BG, Kuo LS, Widell A, Nordenfelt E. Hepatitis B virus DNA in serum and liver is commonly found in Chinese patients with chronic liver disease despite the presence of antibodies to HBsAg. Hepatology. 1993;17(4):538-544.

19. Rehermann B, Ferrari C, Pasquinelli C, Chisari FV. The hepatitis B virus persists for decades after patients' recovery from acute viral hepatitis despite active maintenance of cytotoxic T-lymphocyte response. Nat Med. 1996;2(10):1104-1108.

20. Saraswat S, Banerjee K, Chaudhury N, et al. Post-transfusion hepatitis type B following multiple transfusions of HBsAg-negative blood. J Hepatology. 1996;25(5):639-643.

21. Mason AL, Xu L, Guo L, Kuhns M, Perrillo RP. Molecular basis for persistent hepatitis B virus infection in the liver after clearance of serum hepatitis B surface antigen. Hepatology. 1998;27(6):1736-1742.

22. Silva AE, McMahon BJ, Parkinson AJ, Sjogren MH, Hoofnagle JH, Di Bisceglie AM. Hepatitis B virus DNA in persons with isolated antibody to hepatitis B core antigen who subsequently received hepatitis B vaccine. Clin Infect Dis. 1998;26(4):895-897.

23. Saito T, Shinzawa H, Uchida T, et al. Quantitative DNA analysis of low-level hepatitis B viremia in two patients with serologically negative chronic hepatitis B. J Med Virol. 1999;58(4):325-331.
24. Wang JT, Lee CZ, Chen PJ, Wang TH, Chen DS. Transfusion-transmitted HBV infection in an endemic area: the necessity of more sensitive screening for HBV carriers. Transfusion. 2002;42(12):1592-1597.

25. Allain JP. Occult hepatitis B infection: implication in transfusion. Vox Sang. 2004;86(2):83-91.

26. Coleman PF, Chen YC, Mushahwar IK. Immunoassay detection of hepatitis B surface antigen mutants. J. Med Virol.1999;59(1):19-24.

27. Ireland JH, O'Donnell B, Basuni AA, et al. Reactivity of 13 in vitro expressed hepatitis B surface antigen variants in 7 commercial diagnostic assays. Hepatology. 2000;31(5):1176-1182.

28. Weber B, Melchior W, Gehrke R, Doerr HW, Berger A, Rabenau H. Hepatitis B virus markers in anti-HBc only positive individuals. J Med Virol. 2001;64(3):312-319.

29. Jeantet D, Chemin I, Mandrand B, et al. Cloning and expression of surface antigens from occult chronic hepatitis B virus infections and their recognition by commercial detection assays. J Med Virol. 2004; 73(4):508-515.

30. Weber B. The diagnostic and clinical impact of the genetic variability of the S (surface) gene of hepatitis B virus. J Lab Med. 2004;28:56-59.

31. Weber B. Genetic variability of the $S$ gene of hepatitis B virus: clinical and diagnostic impact. J Clin Virol. 2005;32(2):102-112.

32. Jongerius JM, Wester M, Cuypers HT, et al. New hepatitis B virus mutant form in a blood donor that is undetectable in several hepatitis B surface antigen screening assays. Transfusion. 1998;38(1):56-59.

33. Levicnik-Stezinar S. Hepatitis B surface antigen escape mutant in a first-time blood donor potentially missed by a routine screening assay. Clin Lab. 2004;50(1-2):49-51.

34. Niederhauser C, Weingand T, Candotti D, et al. Fatal outcome of a hepatitis B virus transfusion-transmitted infection. Vox Sang. 2010;98(4): 504-507.

35. Hsu HY, Chang MH, Ni YH, Chen HL. Survey of hepatitis B surface variant infection in children 15 years after a nationwide vaccination programme in Taiwan. Gut. 2004;53(10):1499-1503.

36. Theamboonlers A, Chongsrisawat V, Jantaradsamee P, Poovorawan Y. Variants within the "a" determinant of HBs gene in children and adolescent with a without hepatitis B vaccination as part of Thailand's Expanded Program on Immunization (EPI). Tohoku J Exp Med. 2001; 193(3):197-205.

37. Joller-Jemelka HI, Wicki AN, Grob PJ. Detection of HBs antigen in “anti-HBc alone" positive sera. J Hepatol. 1994;21(2):269-272.

38. Zhang JM, Xu Y, Wang XY, et al. Coexistence of hepatitis B surface antigen (HBsAg) and heterologous subtype-specific antibodies to HBsAg among patients with chronic hepatitis B virus infection. Clin Infect Dis. 2007;44(9):1161-1169.

39. Japanese Red Cross Non-A Hepatitis Research Group. Effect of screening for hepatitis $\mathrm{C}$ virus antibody and hepatitis B virus core antibody on incidence of post-transfusion hepatitis. Lancet. 1991;338(8774): 1040-1041.

40. Kojima M, Shimizu M, Tsuchimochi T, et al. Postransfusion fulminant hepatitis B associated with precore-defective HBV mutants. Vox Sang. 1991;60(1):34-39.

41. Hughes W, Barr A, Dow BC, Follett EA, Barbara JA. A multicentre assessment of the specificity of ten anti-HBc screening assays. Transfus Med. 1995;5(3):225-230.

42. California Blood Bank Society. Homepage on the Internet. AABB TTD Report March 2004. Available from: http://www.cbbsweb.org/hotopics/ hotopics_2004.html. Accessed 2011 Jun 29.

43. Schmidt M, Nübling CM, Scheiblauer H, et al. Anti-HBc screening of blood donors: a comparison of nine anti-HBc tests. Vox Sang. 2006; 91(3):237-243.

44. Aoki SK, Finegold D, Kuramoto IK, et al Significance of antibody to hepatitis B core antigen in blood donors as determined by their serologic response to hepatitis B vaccine. Transfusion. 1993;33(5):362-367.

45. Stramer SL. Anti-HBc testing and donor re-entry. Blood Products Advisory Committee Meeting October2004. Available at: http://www. fda.gov/ohrms/dockets/ac/05/slides/5-4190S1_5b.ppt. Accessed 2011 Jun 29. 
46. Roth WK, Seifried E. The German experience with NAT. Transfus Med. 2002;12(4):255-258.

47. Flanagan P, Charlewood G, Horder S, Drawitsky M, Hollis H. Reducing the risk of transfusion transmitted hepatitis B in New Zealand. Vox Sang. 2005;89(Suppl S2):23. [abstr 4PS-11-03]

48. Niederhauser C, Taleghani BM, Graziani M, Stolz M, Tinguely C, Schneider P. Blood donor screening: how to decrease the risk of transfusion transmitted hepatitis B Virus? Swiss med Wkly. 2008;138(9-10): 134-141.

49. Candotti D, Allain JP. Transfusion-transmitted hepatitis B virus infection. J Hepatology. 2009;51(4):798-809.

50. Roth WK, Weber M, Petersen D, et al. NAT for HBV and anti-HBC testing increase blood safety. Transfusion. 2002;42(7):869-875.

51. Kleinman SH, Kuhns MC, Todd DS, et al, for the Retrovirus Epidemiology Donor Study. Frequency of HBV DNA detection in US blood donors testing positive for the presence of anti-HBc: implications for transfusion transmission and donor screening. Transfusion. 2003; 43(6):696-704.

52. Marusawa $\mathrm{H}$, Uemoto $\mathrm{S}$, Hijikata $\mathrm{M}$, et al. Latent hepatitis $B$ virus infection in healthy individuals with antibodies to hepatitis B core antigen. Hepatology. 2000;31(2):488-495.

53. Hass M, Hannoun C, Kalinina T, Sommer G, Manegold C, Gunther S. Functional analysis of hepatitis B virus reactivating in hepatitis B surface antigen-negative individuals. Hepatology. 2005; 42(1):93-103.

54. Allain JP. International collaborative study proposal for the characterization of occult hepatitis B virus infection identified by nucleic acid or anti-HBc screening. Vox Sang. 2007;92(3):254-257.

55. Roth WK. Hepatitis and blood transfusion. ISBT Science Series. 2007;2: 178-183.

56. Sato S, Ohhashi W, Ihara H, Sakaya S, Kato T, Ikeda H. Comparison of the sensitivity of NAT using pooled donor samples for HBV and that of a serologic HBsAg assay. Transfusion. 2001;41(9):1107-1113.

57. Yoshikawa A, Gotanda Y, Itabashi M, Minegishi K, Nishioka K and the Japanese Red Cross NAT Screening Research Group: HBV NAT positive [corrected] blood donors in the early and late stages of HBV infection: analyses of the window period and kinetics of HBV DNA. Vox Sang. 2005;88(2):77-86.

58. Yoshikawa A, Gotanda Y, Itabashi M, Minegishi K, Kanemitsu K, Nishioka K and the Japanese Red Cross NAT Screening Research Group: hepatitis B NAT virus-positive [corrected] blood donors in the early and late stages of HBV infection: analysis of the WP and kinetics of HBV DNA. Vox Sang. 2005;88(2):77-86. Erratum in Vox Sang. 2005;88(3):223.

59. Matsumoto C, Tadokoro K, Fujimura K, Hirakawa S, Mitsunaga S, Juji T. Analysis of HBV infection after blood transfusion in Japan through investigation of a comprehensive donor specimen repository. Transfusion. 2001;41(7):878-884.

60. Dreier J, Kröger M, Diekmann J, Götting C, Kleesiek K. Low-level viraemia of hepatitis B virus in an anti-HBc- and anti-HBs-positive blood donor. Transfus Med. 2004;14(2):97-103.

61. Gerlich WH. Breakthrough of hepatitis B virus escape mutants after vaccination and virus reactivation. J Clin Virol. 2006;36(Suppl 1): S18-S22.

62. Satake M, Taira R, Yugi H, et al. Infectivity of blood components with low hepatitis B virus DNA levels identified in a lookback program. Transfusion. 2007;47(7):1197-1205.

63. Grob P, Jilg W, Bornhak H, et al. Serological pattern "anti-HBc alone": report on a Workshop. J Med Virol. 2000;62(4):450-455.

64. Brojer E, Grabarczyk P, Liszewski G, Mikulska M, Allain JP, Letowska M. Polish Blood Transfusion Service Viral Study Group. Characterization of HBV DNA +/HBsAg- blood donors in Poland identified by triplex NAT. Hepatology. 2006;44(6):1666-1674.

65. Velati C, Romano L, Fomiatti L, Baruffi L, Zanetti AR, SIMTI Research Group. Impact of nucleic acid testing for hepatitis B virus, hepatitis C virus and human immunodeficiency virus on the safety of blood supply in Italy: a 6-year survey. Transfusion. 2008;48(10):2205-2213.
66. Margaritis AR, Brown SM, Seed CR, Kiely P, D'Agostino B, Keller AJ. Comparison of two automated nucleic acid testing systems for simultaneous detection of human immunodeficiency virus and hepatitis C virus RNA and hepatitis B virus DNA. Transfusion. 2007; 47(10):1783-1793.

67. Nantachit N, Thaikruea L, Thongsawat S, et al. Evaluation of a multiplex human immunodeficiency virus-1, hepatitis $C$ virus, and hepatitis $\mathrm{B}$ virus nucleic acid testing assay to detect viremic blood donors in northern Thailand. Transfusion. 2007;47(10):1803-1808.

68. Li L, Chen PJ, Chen MH, Vhak KF, Lin KS, Tsai SJ. A pilot study for screening blood donors in Taiwan by nucleic acid amplification technology: detecting occult hepatitis B virus infections and closing the serologic window period for Hepatitis C virus. Transfusion. 2008; 48(6):1198-1206.

69. Vermeulen M, Lelie N, Sykes W, et al. Impact of individual-donation nucleic acid testing on risk of human immunodeficiency virus, hepatitis B virus, and hepatitis $\mathrm{C}$ virus transmission by blood transfusion in South Africa. Transfusion. 2009;49(6):1115-1125.

70. Allain JP, Hewitt PE, Tedder RS, Williamson LM. Evidence that anti$\mathrm{HBc}$ but not HBV DNA testing may prevent some HBV transmission by transfusion. Br J Haematol. 1999;107(1):186-195.

71. Burger R, Offergeld R. Testing plasma donations for hepatitis B core antigen (anti-HBc) in order to improve safety of cellular blood components and of quarantined fresh frozen plasma. Bundesgesundheitsbl Gesundheitsforsch Gesundheitsschutz. 2005;48(6):698-699. German.

72. Reesink HW, Engelfriet CP, Henn G, et al. Occult hepatitis B infection in blood donors. Vox Sang. 2008;94(2):153-166.

73. Stolz M, Tinguely C, Graziani M, et al. Efficacy of individual nucleic acid amplification testing in reducing the risk of transfusion-transmitted hepatitis B virus infection in Switzerland, a low endemic region. Transfusion. 2010;50(12):2695-2706.

74. Tabuchi A, Tanaka J, Katayama K, et al. Titration of hepatitis B virus infectivity in the sera of pre-acute and late-acute phases of HBV infection: transmission experiments to chimeric mice with human liver repopulated hepatocytes. J Med Virol. 2008;80(12):2064-2068.

75. Jilg W, Sieger E, Zachoval R, Schätzl H. Individuals with antibodies against hepatitis $\mathrm{B}$ core antigen as the only serological marker for hepatitis B infection: high percentage of carriers of hepatitis B and C virus. J Hepatol. 1995;23(1):14-20.

76. Cardoso MS, Koerner K, Kubanek B. Mini-pool screening by nucleic acid testing for hepatitis $\mathrm{B}$ virus, hepatitis $\mathrm{C}$ virus and HIV: preliminary results. Transfusion. 1998;38(10):905-907.

77. Tomono $T$ and the Japanese Red Cross NAT Screening Research. Status of NAT Screening for HCV, HIV and HBV: experience in Japan. In: Brown F, Seitz R, editors. Advances in transfusion safety. Karger, Basel: Developments in Biologicals. Verlag; 2001:29-39.

78. Minegishi K, Yoshikawa A, Kishimoto S, et al. Japanese Red Cross NAT Screening Research Group. Superiority of minipool nucleic acid amplification technology for hepatitis B virus over chemiluminescence immunoassay for hepatitis B surface antigen screening. Vox Sang. 2003; 84(4):287-291.

79. Busch MP. Should HBV DNA NAT replace HBsAg and/or anti-HBc screening of blood donors? Transfus Clin Biol. 2004;11(1):26-32.

80. Kuhns MC, Kleinman SH, McNamara AL, Rawal B, Glynn S, Busch MP. Lack of correlation between HBsAg and HBV DNA levels in blood donors who test positive for HBsAg and anti-HBc: implication for future HBV screening policy. Transfusion. 2004;44(9):1332-1339.

81. Kleinman S, Strong DM, Tegmeier G, et al. Hepatitis B (HBV) DNA screening of blood donation in minipools with the COBAS AmpliScreen HBV test. Transfusion. 2005;45(8):1247-1257.

82. Allain JP, Candotti D, Soldan K, et al. The risk of hepatitis B virus infection by transfusion in Kumasi, Ghana. Blood. 2003;101(6): 2419-2425.

83. Kiely P, Stewart Y, Castro L. Analysis of voluntary blood donors with biologic false reactivity on chemiluminescent immunoassays and implications for donor management. Transfusion. 2003;43(5): 584-590. 
84. El Ekiaby M, Allain JP, Linnen J, Lelie N. Hepatitis B virus DNA and hepatitis B surface antigen concentrations in Egyptian blood donors: limits of detection of ultrasensitive nucleic acid screening tests in $\mathrm{HBsAg}$ carriers [abstract]. Vox Sang. 2009;96(Suppl 1);2A-S04-S02:17-18.

85. Penna A, Artini M, Cavalli A, et al. Long-lasting memory T cell responses following self-limited acute Hepatitis B. J Clin Invest. 1996; 98(5):1185-1194.

86. Yotsuyanagi $\mathrm{H}$, Yasuda $\mathrm{K}$, Iino $\mathrm{S}$, et al. Persistent viremia after recovery from self-limited acute hepatitis B. Hepatology. 1998;27(5): 1377-1382.

87. Brechot C, Thiers V, Kremsdorf D, Nalpas B, Pol S, Paterlini-Brechot P. Persistent hepatitis B virus infection in subjects without hepatitis B surface antigen: clinically significant or purely "occult"? Hepatology. 2001;34(1):194-203.

88. Alhababi F, Sallam TA, Tong CY. The significance of anti-HBc only in the clinical virology laboratory. J Clin Virol. 2003;27(2):162-169.

89. Busch MP. Prevention of transmission of hepatitis B, hepatitis C and human immunodeficiency virus infections through blood transfusion by anti-HBc testing. Vox Sang. 1998;74(Suppl 2):147-154.

90. Dodd RY, Reesink HW, Busch MP, et al. ISBT international forum: do surrogate tests improve the safety of the blood supply? Vox Sang.1995;69(3):280-291

91. Antar W, El-Shokry MH, Abd El Hamid WA, Hely MF. Significance of detecting anti-HBc among Egyptian male blood donors negative for HBsAg. Transfus Med. 2010;20(6):409-413.

92. Glynn SA, Kleinma SH, Wright DJ, Busch MP for the REDS group. International application of the incidence rate/window period model. Transfusion. 2002;42(8):966-972.

93. Candotti D, Grabarczyk P, Ghiazza P, et al. Characterization of occult hepatitis $\mathrm{B}$ virus form blood donors carrying genotype $\mathrm{A} 2$ or genotype D strains. J Hepatol. 2008;49(4):537-547.

94. Candotti D, Allain JP. Transfusion-transmitted hepatitis B virus infection. J Hepatol. 2009;51(4):798-809.

95. Dow BC, Peterkin MA, Green RHA, Cameron SO. Hepatitis B virus transmission by blood donation negative for hepatitis B surface antigen, antibody to HBsAg, antibody to hepatitis core antigen and HBV DNA. Vox Sang. 2001;81(2):140.

96. Manzini P, Girotto M, Borsotti R, et al. Italian blood donors with anti-HBc and occult hepatitis B virus infection. Haematologica. 2007 92(12):1664-1670.

97. Manzini P, Abate ML, Valpreda C, et al. Evidence of acute primary occult hepatitis B virus infection in an Italian repeat blood donor. Transfusion. 2009;49(4):757-764.

98. Hoofnagle JH, Seefe LB, Bales ZB, Zimmermann HJ. Type B hepatitis after transfusion with blood containing antibody to hepatitis B core antigen. N Engl J Med. 1978;298(25):1379-1383.

99. Mosley JW, Stevens CE, Aach RD, et al. Donor screening for antibody to hepatitis core antigen and hepatitis B virus infection in transfusion recipients. Transfusion. 1995;35(1):5-12.

100. Elghouzzi MH, Courouce AM, Magnius LO, Lunel F, Lapierre V. Transmission of hepatitis B virus by HBV-negative blood transfusion. Lancet. 1995;346(8980):964.

101. Levicnik-Stezinar S, Rahne-Potokar U, Candotti D, Lelie N, Allain JP. Anti-HBs positive occult hepatitis B virus carrier blood infectious in two transfusion recipients. J Hepatol. 2008;48(6):1022-1025.

102. Hollinger FB. Hepatitis B virus infection and transfusion medicine: science and the occult. Transfusion. 2008;48(5):1001-1026.

103. Tegtmeier G, Henderson S, McNamara A, Kuhns M. Contribution of anti-HBc screening to blood safety at a regional blood center in the United States [abstract]. Transfusion. 1997;(Suppl 37):11S.

104. Komiya Y, Katayama K, Yugi H, et al. Minimum infectious dose of hepatitis B virus in chimpanzees and difference in the dynamics of viremia between genotype A and genotype C. Transfusion. 2008;48(2): 286-294.

105. Yugi H, Hino S, Satake M, Tadodoro K. Implementation of donor screening for infectious agents transmitted by blood by nucleic acid technology in Japan. Vox Sang. 2005;89(4):265.
106. Yugi H, Mizui M, Tanaka J, Yoshizawa H. Hepatitis B virus (HBV) screening strategy to ensure the safety of blood for transfusion through a combination of immunological testing and nucleic acid amplification testing - Japanese experience. J Clin Virol. 2006;36(Suppl 1): S56-S64.

107. Tadokoro K. The new Japanese blood law: its impact on blood safety and usage. Dev Biol (Basel). 2007;127:161-168.

108. Comanor L, Holland P. Hepatitis B virus blood screening: unfinished agenda. Vox Sang. 2006;91(1):1-12.

109. Henning H, Puchta I, Luhm J, Schlenke P, Georg S, Kirchner H. Frequency and load of hepatitis B virus DNA in first-time blood donors with antibodies to hepatitis core antigen. Blood. 2002;100(7): 2637-2641.

110. Chevrier MC, St-Louis M, Perreault J, et al. Detection and characterization of hepatitis B virus of anti-hepatitis B core antigen-reactive blood donors in Quebec with an in-house nucleic acid assay. Transfusion. 2007;47(10):1794-1802.

111. O’Brien S, Yi Q-L, Fan W, Scalia V, Kleinman SH, Vamvakas EC. Current incidence and estimated resiudal risk of transfusion-transmitted infections in donations made to Canadian Blood Services. Transfusion . 2007;47(2):316-325

112. Hourfar MK, Jork C, Schottstedt V, et al. German Red Cross NAT Study Group. Experience of German Red Cross blood donor services with nucleic acid testing: results of screening more than 30 million blood donations for human immunodeficiency virus-1, hepatitis $\mathrm{C}$ virus and hepatitis B virus. Transfusion. 2008;48(8):1558-1566.

113. Linauts S, Saldana J, Strong DM. PRISM HBsAg detection of hepatitis B virus minipool nucleic acid testing yield samples. Transfusion. 2008; 48(7):1376-1382.

114. Stramer SL. Current risk of transfusion-transmitted agents: a review. Arch Pathol Lab Med. 2007;131(5):702-707.

115. Stramer SL, Wend U, Candotti D, et al. Nucleic acid testing to detect HBV infection in blood donors. N Engl J Med. 2011;364(3): 236-247.

116. Mine H, Emura H, Miyamoto M, et al. High throughput screening of 16 million serologically negative blood donors for hepatitis B virus, hepatitits $\mathrm{C}$ virus and human immunodeficiency virus type- 1 by nucleic acid amplification tewting with specific and sensitive multiplex reagent in Japan. J Virol Methods. 2003;112(1-2):145-151.

117. Ramia S, Ramlawi F, Kanaan M, Klyme S, Naman R. Frequency and significance of antibodies against hepatitis B core (anti-HBc) antigen as the only serological marker for hepatitis B infection in Lebanese blood donors. Epidemiol Infect. 2005;133(4):695-699.

118. Katsoulidou A, Moschidis Z, Sypsa V, et al. Analytical and clinical sensitivity of the Procleix Ultrio HIV-1/HCV/HBV assay in samples with a low viral load. Vox Sang. 2007;92(1):8-14.

119. Owusu-Ofori S, Temple J, Sakrodie F, Anokwa M, Candotti D, Allain JP. Predonation screening of blood donors with rapid tests: implementation and efficacy of a novel approach to blood safety in resource-poor settings. Transfusion. 2005;45(2):133-140.

120. Soedarmono YSM, Suyati MF, Purwati LB, Arfat F. Nucleic acid testing of first time Indonesian blood donors. Vox Sang. 2005;89 (Suppl S2):24. [abstract 4PS-11-05]

121. Wong I, Lam S, Teo D. Overview of nucleic acid testing (NAT) on blood donations in Singapore. Vox Sang. 2005;89(1):19-26.

122. Makroo RN, Choudhury N, Jagannathan L, et al. Multicenter evaluation of individual donor nucleic acid testing (NAT) for simultaneous detection of human immunodeficiency virus- 1 and hepatitis $\mathrm{B}$ and $\mathrm{C}$ viruses in Indian blood donors. Indian J Med Res. 2008;17:140-147.

123. Phikulsod S, Oota S, Tirawatnapong T, et al. Working Group for NAT Study in Thai Blood Donations. One-year experience of nucleic acid technology testing for human immunodeficiency virus Type 1, hepatitis $\mathrm{C}$ virus and hepatitis B virus in Thai blood donations. Transfusion. 2009;49(6):1126-1135.

124. Weusten J, Vermeulen M, van Drimmelen H, Lelie N. Refinement of a viral transmission risk model for blood donations in seroconversion window phase screened by nucleic acid testing in different pool sizes and repeat test algorithms. Transfusion. 2011;51(1):203-215. 
125. Koppelman M, Assal A, Chuddy M, et al. Multicenter performance evaluation of a multiplex transcription mediated amplification assay for screening of human immunodeficiency virus-1 RNA, hepatitis C virus RNA and hepatitis B virus DNA in blood donations. Transfusion. 2005;45(8):1258-1266.

126. Yotsuyanagi H, Yasuda K, Moriya K, et al. Frequent presence of $\mathrm{HBV}$ in the sera of HBsA-negative, anti-HBc positive blood donors. Transfusion. 2001;41(9):1093-1099.

127. Jackson BR, Busch MP, Stramer SL, AuBuchon JP. The costeffectivness of NAT for HIV, HCV and HBV in whole-blood donations. Transfusion. 2003;43(6):721-729.

128. Dodd RY, Notari EP, Stramer SL. Current prevalence and incidence of infectious disease markers and estimated window-period risk in the American Red Cross blood donor population. Transfusion. 2002; 42(8):975-979.

129. Coste J, Reesink HW, Engelfriet CP, et al. International forum. Implementation of donor screening for infectious agents transmitted by blood by nucleic acid technology: update to 2003. Vox Sang. 2005; 88(4):289-303.

130. Niederhauser C, Schneider P, Fopp M, Ruefer A, Lévy G. Incidence of viral markers and evaluation of the estimated risk in the Swiss blood donor population from 1996 to 2003. Euro Surveill. 2005; 10(2):7-8.

131. Offergeld R, Faensen D, Ritter S, Hamouda O. Human immunodeficiency virus, hepatitis $\mathrm{C}$ and $\mathrm{B}$ infections among blood donors in Germany 2000-2002: risk of virus transmission and the impact of nucleic acid amplification testing. Euro Surveill. 2005;10(2):8-11.

132. Soldan K, Davison K, Dow B. Estimates of the frequency of HBV, $\mathrm{HCV}$ and HIV infectious donations entering the blood supply in the United Kindom, 1996 to 2003. Euro Surveill. 2005;10(2):17-19.

133. Seed CR, Kiely P, Keller AJ. Residual risk of transfusion transmitted human immunodeficiency virus, hepatitis B virus, hepatitis C virus and human T lymphotrophic virus. Intern Med J. 2005;35(10): 592-598.

134. Laperche S, Maniez M, Barlet V, et al; Transfusion-Transmissible Agents Working Group, French National Society of Blood Transfusion. A revised method for estimatin hepatitis B virus transfusion residual risk based on antibody to hepatitis B core antigen incident cases. Transfusion. 2008;48(11):2308-2314.

135. Center for Biologics Evaluation and Research. Blood Products Advisory Committee, 94th Meeting, Gaithersburg, MD, April 1, 2009 (transcript). Available from: http://www.fda.gov/downloads/ AdvisoryCommittees/CommitteesMeetingMaterials/BloodVaccinesandOtherBiologics/BloodProductsAdvisoryCommittee/UCM155628. pdf. Accessed 2011 Jun 29.

136. Tosti ME, Solinas S, Prati D, et al. An estimate of the current risk of transmitting blood-borne infections through blood transfusion in Italy. Br J Haematol. 2002;117(1):215-219.

137. Shang G, Seed CR, Wang F, Nie D, Farrugia A. Residual risk of transfusion-transmitted viral infections in Shenzhen, China, 2001 through 2004. Transfusion. 2007;47(3):529-539.

138. Alvarez do Barrio M, Gonzalez Diez R, Hernandez Sanchez JM, Oyonarte Gomez S. Residual risk of transfusion-transmitted viral infections in Spain, 1997-2002, and impact of nucleic acid testing. Euro Surveill. 2005;10(2):20-22.
139. Zou S, Stramer SL, Notari EP, et al. Current incidence and residual risk of hepatitis B infection among blood donors in the United States. Transfusion. 2009;49(8):1609-1620.

140. O'Brien SF, Xi G, Fan W, et al. Epidemiology of hepatitis B in Canada blood donors. Transfusion. 2008;48(11):2323-2330.

141. Daniels D, Grytal S, Wasley A. Surveillance for acute viral hepatitis - United States, 2007. MMWR Surveill Summ. 2009;58(3): $1-27$.

142. Kleinman SH, Busch MP. Risks transfusion transmitted infection: direct estimation and mathematical modelling. Bailleres Best Pract Res Clin Haematol. 2000;13(4):631-649.

143. Korelitz JJ, Busch MP, Kleinman SK, et al. For the National Heart Lung and Blood Institute Retrovirus Epidemiology Donor Study. A method for estimating hepatitis B virus incidence rates in volunteer donors. Transfusion. 1997;37(6):634-640.

144. Kleinman SH, Busch MP. Assessing the impact of HBV NAT on window period reduction and residual risk. J Clin Virol. 2006; 36(Suppl 1):S23-S29.

145. Raimondo G, Allain JP, Brunetto MR, et al. Statements from the Taormina expert meeting on occult hepatitis B virus infection. J Hepatol. 2008;49(4):652-657.

146. Yoshikawa A, Gotanda Y, Minegishi K, et al. Japanese Red Cross NAT Screening Research Group. Lengths of hepatitis B viremia and antigenemia in blood donors: preliminary evidence of occult (HBsAg-negative) infection in the acute stage. Transfusion. 2007;47(7):1162-1171.

147. Chalmers TC, Koff RS, Grady GF. A note on fatality in serum hepatitis. Gastroenterology. 1965;49:22-26.

148. Inaba S, Ito A, Miyata $\mathrm{Y}$, et al. Individual nucleic amplification technology does not prevent all hepatitis B virus transmission by blood transfusion. Transfusion. 2006;46(11):2028-2029.

149. Gerlich WH, Wagner FF, Chudy M, et al. HBsAg non-reactive HBV infection in blood donors: transmission and pathogenicity. J Med Virol. 2007;79:S32-S36.

150. Aach RD, Alter HJ, Hollinger FB, et al. Risk of transfusing blood containing antibody to hepatitits-B surface antigen. Lancet. 1974;2(7874): 190-193.

151. Chang MW. Impact of hepatitis B vaccination on hepatitis disease and nucleic acid testing in high-prevalence populations. J Clin Virol. 2006;36(Suppl 1):S45-S50.

152. Ni YH, Huang LM, Chang MH, et al. Two decades of universal hepatitis B vaccination in Taiwan: impact and implication for future strategies. Gastroenterology. 2007;132(4):1287-1293.

153. Nardone A, Anastassopoulou CG, Theeten H, et al. A comparison of hepatitis B seroepidemiology in ten European countries. Epidemiol Infect. 2009;137(7):961-969.

154. Singh H, Pradhan M, Singh RL, et al. High frequency of hepatitis B virus infection in patients with beta-thalassemia receiving multiple transfusions. Vox Sang. 2003;84(4):292-299.

155. Prince AM, Lee DH, Brotman B. Infectivity of blood from PCRpositive, HBsAg-negative, anti-HBs-positive cases of resolved hepatitis B infection. Transfusion. 2001;41(3):329-332.

156. Alter HJ, Hougthon M. Hepatitis $C$ virus and elimination post transfusion hepatitis. Nat Med. 2000;6(10):1082-1086.

157. Hoofnagle JH. Post-transfusion hepatitis B. Transfusion. 1990;30(5): 384-386.
Journal of Blood Medicine

\section{Publish your work in this journal}

The Journal of Blood Medicine is an international, peer-reviewed, open access, online journal publishing laboratory, experimental and clinical aspects of all topics pertaining to blood based medicine including but not limited to: Transfusion Medicine; Blood collection, Donor issues, Transmittable diseases, and Blood banking logistics; Immunohematology; Artificial and alternative

\section{Dovepress}

blood based therapeutics; Hematology; Biotechnology/nanotechnology of blood related medicine; Legal aspects of blood medicine; Historical perspectives. The manuscript management system is completely online and includes a very quick and fair peer-review system. Visit http://www.dovepress.com/ testimonials.php to read real quotes from published authors. 